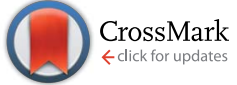

Cite this: RSC Adv., 2017, 7, 17063

\title{
Synthesis, structures and catalytic activity of cyclometalated rhenium complexes $\dagger$
}

\author{
Ruichen Sun, Tian Wang, Shaowei Zhang, Xiaodan Chu and Bolin Zhu*
}

Thermal reactions of aryl-substituted phosphines or phosphinites with $\mathrm{Re}_{2}(\mathrm{CO})_{10}$ in chlorobenzene resulted in the corresponding five-membered cyclometalated rhenium complexes (1-5) via an intramolecular activation of the $\mathrm{C}\left(\mathrm{sp}^{2}\right)-\mathrm{H}$ or $\mathrm{C}\left(\mathrm{sp}^{3}\right)-\mathrm{H}$ bond. The only exception occurred in the case of (1-naphthyl) diisopropylphosphinite, which gave a diphosphinite-substituted dinuclear rhenium complex 6 . Competition reaction indicated that the aromatic $\mathrm{C}\left(\mathrm{sp}^{2}\right)-\mathrm{H}$ bond is more likely to be activated than the $\mathrm{C}\left(\mathrm{sp}^{3}\right)-\mathrm{H}$ bond under the same conditions. Photolysis of 1 or 2 in $\mathrm{CHX}_{3}$ led to the cleavage of the $\mathrm{Re}-\mathrm{C}$ $\sigma$ bond to yield corresponding phosphine-substituted tetracarbonyl rhenium halides 7-10. Complex 1 reacted with $\mathrm{CF}_{3} \mathrm{COOH}$ in $\mathrm{CH}_{2} \mathrm{Cl}_{2}$ to give addition product 11. Photolysis of cyclorhenated complexes 13 with a series of aryl halides in benzene resulted in the stoichiometric formation of biphenyl, together with corresponding phosphine-substituted tetracarbonyl rhenium halides (7, 9, 10, 12, and 13). When base was introduced into the above reaction, a catalytic system was established. Under optimized conditions, complex 1 provided moderate yield of biphenyl in a couple of hours at a [Re] : substrate ratio of $1: 200$. Molecular structures of complexes $1,6,9$, and 11 were determined by X-ray diffraction.

Received 15th December 2016
Accepted 14th March 2017

DOI: $10.1039 / c 6 r a 28263 f$

rsc.li/rsc-advances or a mixture thereof). In this paper, we report the synthesis of a series of cyclometalated rhenium complexes starting from the precursor $\mathrm{Re}_{2}(\mathrm{CO})_{10}$, as well as their catalytic activity in direct arylation of arenes with aryl halides.

Cyclometalation has always been one of the most widely investigated reactions in the field of organometallic chemistry since it was first discovered in the early 1960s. ${ }^{1}$ The reason that cyclometalation has received such considerable attention is mainly due to the following three aspects: (i) it represents probably the mildest route for the intramolecular activation of $\mathrm{C}-\mathrm{H}$ bonds, and forms a cyclometalated complex containing a new $\mathrm{M}-\mathrm{C} \sigma$ bond. (ii) Cyclometalated complexes have wide applications in many fields, such as photosensitizers for solar cells $^{2}$ and OLED materials. ${ }^{3}$ (iii) As catalysts for a wide range of reactions, including metathesis reactions, ${ }^{4}$ cross-coupling reactions, ${ }^{5}$ and transfer hydrogenation reactions. ${ }^{6}$ Of all transition metals, cyclometalated rhenium complexes have recently attracted more and more attention due to their luminescent properties, which may have potential as liquid crystals, ${ }^{7}$ and in particular, their indispensable role in many catalytic cycles, including the rhenium-catalyzed annulation reaction of aromatic imines with alkynes, ${ }^{8}$ alkenes, ${ }^{9}$ or aldehyde, ${ }^{10}$ and alkylation of 2-phenyl, or alkenyl-substituted pyridine. ${ }^{11}$ Generally, the most widely used precursors for cyclorhenation are $\operatorname{Re}(\mathrm{X})(\mathrm{CO})_{5}(\mathrm{X}=\mathrm{H}, \mathrm{Me}, \mathrm{Cl}$, or $\mathrm{Br})$ and $\operatorname{Re}(\mathrm{Cp}) \mathrm{L}_{3}\left(\mathrm{~L}=\mathrm{CO}, \mathrm{PR}_{3}\right.$,

Tianjin Key Laboratory of Structure and Performance for Functional Molecules, Key Laboratory of Inorganic-Organic Hybrid Functional Material Chemistry, Ministry of Education, College of Chemistry, Tianjin Normal University, Tianjin 300387, PR China.E-mail: hxxyzbl@gmail.com; Fax: +86-22-23766532; Tel: +86-22-23766515

$\uparrow$ CCDC 1520723-1520726. For crystallographic data in CIF or other electronic format see DOI: 10.1039/c6ra28263f

\section{Results and discussion}

Reaction of $\operatorname{Re}_{2}(\mathrm{CO})_{10}$ with (1-naphthyl)diphenyl phosphine or diisopropyl(1-naphthyl) phosphine

A solution of $\operatorname{Re}_{2}(\mathrm{CO})_{10}$ and 2 equiv. of (1-naphthyl)diphenyl phosphine or diisopropyl(1-naphthyl) phosphine in chlorobenzene was refluxed overnight to result in corresponding fivemembered cyclorhenated complex 1 or $\mathbf{2}$ in good yields (Scheme 1). Obviously, the formation of complexes 1 and 2 goes through an intramolecular activation of $\mathrm{C}\left(\mathrm{sp}^{2}\right)-\mathrm{H}$ bond on the adjacent $\alpha$ position of naphthyl ring. The ${ }^{1} \mathrm{H}$ NMR spectrum of 1 showed six peaks centered at $\delta 8.21(1 \mathrm{H}), 7.95(1 \mathrm{H}), 7.68(1 \mathrm{H}), 7.60(1 \mathrm{H})$, 7.55-7.49 $(1 \mathrm{H}$, overlapping with peaks for protons on two phenyl rings), $7.35(1 \mathrm{H})$ corresponding to six protons of the metalated naphthyl group. More distinctly, the ${ }^{1} \mathrm{H}$ NMR

$$
\begin{aligned}
& +\mathrm{Re}_{2}(\mathrm{CO})_{10} \frac{\mathrm{C}_{6} \mathrm{H}_{5} \mathrm{Cl}}{\triangle} \\
& 1(\mathrm{R}=\mathrm{Ph}) \\
& 2\left(\mathrm{R}={ }^{\mathrm{i}} \mathrm{Pr}\right)
\end{aligned}
$$

Scheme 1 Reactions of 1-naphthyl-substituted phosphines with $\operatorname{Re}_{2}(\mathrm{CO})_{10}$. 
spectrum of 2 exhibited five well-separated multiplets at $\delta 8.16$ $(1 \mathrm{H}), 7.85(1 \mathrm{H}), 7.58(2 \mathrm{H}), 7.43(1 \mathrm{H}), 7.28(1 \mathrm{H})$ for resonance of six protons on the metalated naphthyl group. The IR spectra of 1 and 2 ( $\mathrm{KBr}$ film) indicated the expected strong $\nu(\mathrm{CO})$ absorptions in the range $2084-1925 \mathrm{~cm}^{-1}$ for terminal carbonyls. The structure of 1 was further confirmed by single-crystal diffraction analysis, which is shown in Fig. 1, with selected bond lengths and angles. It reveals an octahedral geometry with the rhenium(I) center coordinated by four carbonyl groups, one phosphorus atom $\mathrm{P}(1)$, and one metalated carbon atom $\mathrm{C}(3)$, in which $\mathrm{P}(1)$ and $\mathrm{C}(3)$ are mutually adjacent. Re-P bond length is 2.4413(9) ̊, a litter longer than that $(2.428(3) \AA)$ in fourmembered cyclorhenated analogue $\mathrm{Re}(\mathrm{CO})_{4}\left(\mathrm{PPh}_{2} \mathrm{CH}_{2} \mathrm{CH}_{2}\right) \cdot{ }^{12}$

\section{Reaction of $\operatorname{Re}_{2}(\mathrm{CO})_{10}$ with diisopropyl(o-methylphenyl) phosphine}

Having demonstrated that phosphine ligand could be employed as a donor group for metalation of a naphthyl $\mathrm{C}\left(\mathrm{sp}^{2}\right)-\mathrm{H}$ bond in complexes 1 and 2, we decided to test whether it could also promote activation of a $\mathrm{C}\left(\mathrm{sp}^{3}\right)-\mathrm{H}$ bond. The corresponding reaction of $\operatorname{Re}_{2}(\mathrm{CO})_{10}$ with diisopropyl $(o$-methylphenyl) phosphine was carried out, which afforded a product 3 in $50 \%$ yield (Scheme 2). The ${ }^{1} \mathrm{H}$ NMR spectrum of 3 showed three multiplets at $\delta 7.38(1 \mathrm{H}), 7.24(2 \mathrm{H}), 7.04(1 \mathrm{H})$ duo to four protons on the phenyl ring, one multiplet at $\delta 2.49(2 \mathrm{H})$ for methenyl signal, and two doublets of doublets at $\delta 1.20(6 \mathrm{H})$ and $1.05(6 \mathrm{H})$ for signals of four methyls on two isopropyl groups. However, there was no signal for the methyl on the phenyl ring; instead one multiple at $\delta 2.50$, integrating to $2 \mathrm{H}$, assigned to a metal-bound

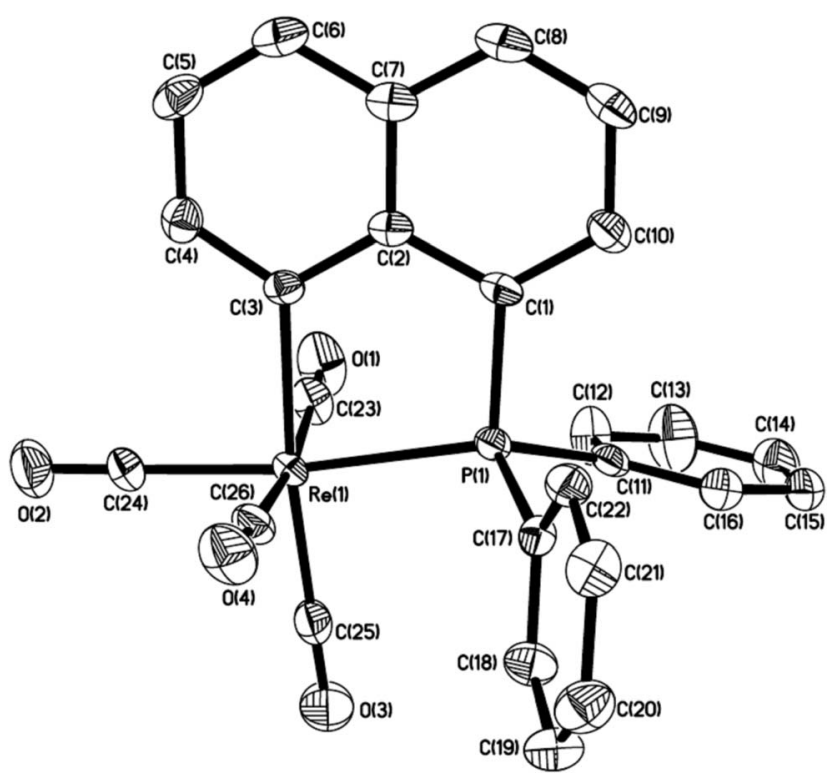

Fig. 1 Thermal ellipsoid drawing of 1 showing the labeling scheme and $50 \%$ probability ellipsoids; hydrogens are omitted for clarity. Selected bond lengths $[\AA]$ and angles $\left[{ }^{\circ}\right]$ are $\operatorname{Re}(1)-P(1) 2.4413(9), P(1)-$ $C(1)$ 1.812(3), $\operatorname{Re}(1)-C(23) 1.987(4), \operatorname{Re}(1)-C(24) 1.960(4), \operatorname{Re}(1)-C(25)$ 1.969(4), $\operatorname{Re}(1)-C(26) \quad 2.003(4), \quad \angle C(3)-\operatorname{Re}(1)-C(25) \quad 173.87(14)$, $\angle C(24)-\operatorname{Re}(1)-P(1) \quad 170.15(12), \quad \angle C(23)-\operatorname{Re}(1)-C(26) \quad 171.80(16)$, $\angle C(3)-\operatorname{Re}(1)-P(1) 79.05(9), \angle \operatorname{Re}(1)-P(1)-C(1)$ 103.52(12).

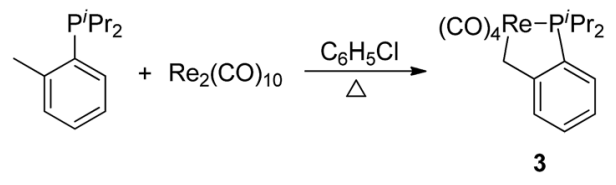

Scheme 2 Reaction of diisopropyl(o-methylphenyl) phosphine with $\mathrm{Re}_{2}(\mathrm{CO})_{10}$.

$\mathrm{CH}_{2}$. These resonances confirm the expected $\mathrm{C}\left(\mathrm{sp}^{3}\right)-\mathrm{H}$ bond activation.

\section{Reactions of $\operatorname{Re}_{2}(\mathrm{CO})_{10}$ with diisopropyl(2-methylnaphthyl) phosphine}

Since both $\mathrm{C}\left(\mathrm{sp}^{2}\right)-\mathrm{H}$ bond and $\mathrm{C}\left(\mathrm{sp}^{3}\right)-\mathrm{H}$ bond could be activated in cyclometalation of $\mathrm{Re}_{2}(\mathrm{CO})_{10}$ with phosphines, we were curious about the relative activity between them. Therefore, diisopropyl(2-methylnaphthyl) phosphine was chosen as the ligand, which provides both $\mathrm{C}\left(\mathrm{sp}^{2}\right)-\mathrm{H}$ and $\mathrm{C}\left(\mathrm{sp}^{3}\right)-\mathrm{H}$ bonds at the appropriate positions, to test the competition reaction. Therefore, reaction of $\operatorname{Re}_{2}(\mathrm{CO})_{10}$ with diisopropyl(2-methylnaphthyl) phosphine under the above-mentioned conditions was performed, which gave a product 4 (Scheme 3 ). The ${ }^{1} \mathrm{H}$ NMR spectrum of 4 showed four multiplets in the aromatic region, all integrating to $5 \mathrm{H}$ due to the naphthyl ring, and a doublet at $\delta$ 2.71, assigned to signal for the methyl on the naphthyl ring. These resonances indicated that the aromatic $\mathrm{C}\left(\mathrm{sp}^{2}\right)-\mathrm{H}$ bond is selectively activated in the reaction to form the five-membered cyclometalated complex 4 . The reason that the aromatic $\mathrm{C}\left(\mathrm{sp}^{2}\right)-$ $\mathrm{H}$ bond activation is favored over $\mathrm{C}\left(\mathrm{sp}^{3}\right)-\mathrm{H}$ bond activation is probably owing to the higher thermal stability of aryl hydrogen activated product when compared to alkyl hydrogen activated product.

\section{Reactions of $\operatorname{Re}_{2}(\mathrm{CO})_{10}$ with phosphinites}

In order to explore applicable scope of this type of cyclometalation, ligand was extended to phosphinite. Therefore reaction of $\mathrm{Re}_{2}(\mathrm{CO})_{10}$ with $o$-methylphenyl diisopropylphosphinite was examined, which produced the corresponding fivemembered cyclometalated complex 5 (Scheme 4). The ${ }^{1} \mathrm{H}$ NMR spectrum of 5 showed three multiplets $(\delta 7.55,6.84$, and 6.71$)$ in the aromatic region, each integrating to $1 \mathrm{H}$ due to the phenyl ring, and a singlet at $\delta 2.25$, assigned to signal for the methyl on the phenyl ring. These ${ }^{1} \mathrm{H}$ NMR information confirms an ortho aromatic $\mathrm{C}\left(\mathrm{sp}^{2}\right)-\mathrm{H}$ bond activation.

However, when $\mathrm{Re}_{2}(\mathrm{CO})_{10}$ reacted with another phosphinite, 1-naphthyl diisopropylphosphinite under the above-mentioned conditions, the reaction did not produce the similar five-

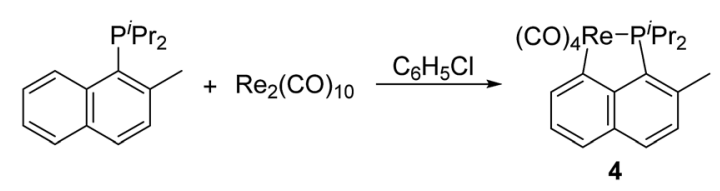

Scheme 3 Reaction of diisopropyl(2-methylnaphthyl) phosphine with $\mathrm{Re}_{2}(\mathrm{CO})_{10}$ 


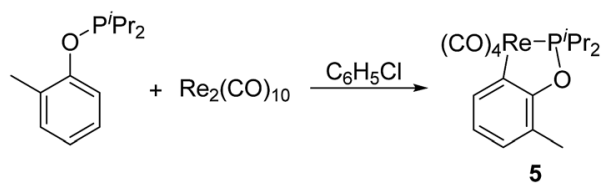

Scheme 4 Reaction of o-methylphenyl diisopropylphosphinite with $\mathrm{Re}_{2}(\mathrm{CO})_{10}$.

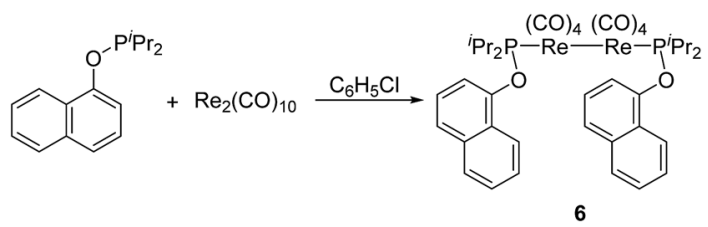

Scheme 5 Reaction of 1-naphthyl diisopropylphosphinite with $\mathrm{Re}_{2}(\mathrm{CO})_{10}$.

membered cyclometalated complex, instead a dinuclear complex 6 was obtained (Scheme 5). The ${ }^{1} \mathrm{H}$ NMR spectrum of 6 showed six multiplets in the aromatic region, all integrating to $7 \mathrm{H}$ corresponding to protons of the naphthyl ring. These resonances indicate the absence of aromatic $\mathrm{C}\left(\mathrm{sp}^{2}\right)-\mathrm{H}$ bond activation. The structure of 6 was further confirmed by singlecrystal diffraction analysis, which is shown in Fig. 2, with selected bond lengths and angles. It consists of a pair of square pyramidal $\operatorname{Re}(\mathrm{CO})_{4}(\mathrm{P})$ units linked by a Re-Re bond. Each phosphinite ligand is located at the top of the pyramid. Two sets of carbonyl groups bounded to two rhenium atoms occur as the staggered conformation. Re-Re bond length is 3.0606(5) $\AA$, a litter longer than that $(3.04 \AA)$ in $\operatorname{Re}_{2}(\mathrm{CO})_{10} \cdot{ }^{13}$

\section{Cleavage of the cyclometalated Re-C bond of 1 or 2}

$\mathrm{Lu}$ has reported the chemical behavior of the similar $\mathrm{N}$-contained cyclorhenated complexes, including the electrophilic addition reactions of cyclorhenated complexes with $\mathrm{HBr}, \mathrm{RCO}_{2} \mathrm{H}$, or $\mathrm{I}_{2}$, which caused the opening of the metallacyclic ring to generate the corresponding rhenium products. ${ }^{\mathbf{1 4}}$ For comparison of

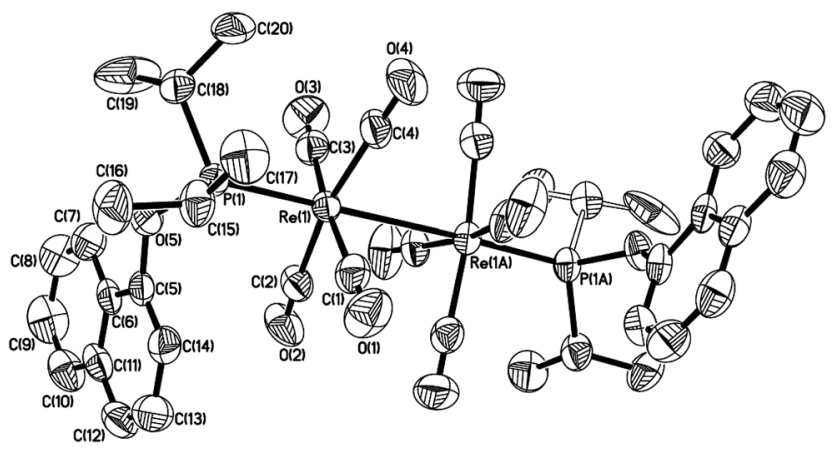

Fig. 2 Thermal ellipsoid drawing of 6 showing the labeling scheme and $50 \%$ probability ellipsoids; hydrogens are omitted for clarity. Selected bond lengths $[\AA \AA]$ and angles $\left[^{\circ}\right]$ are $\operatorname{Re}(1)-\operatorname{Re}(1 \mathrm{~A}) 3.0606(5)$, $\operatorname{Re}(1)-P(1)$ 2.3419(15), $\operatorname{Re}(1)-C(1)$ 1.982(10), $\operatorname{Re}(1)-C(2) 1.977(7), \operatorname{Re}(1)-$ $C(3)$ 1.977(10), $\operatorname{Re}(1)-C(4)$ 1.958(8), $\angle P(1)-\operatorname{Re}(1)-\operatorname{Re}(1 \mathrm{~A})$ 177.56(4), $\angle C(1)-\operatorname{Re}(1)-C(3) 173.0(3), \angle C(2)-\operatorname{Re}(1)-C(4) 168.1(3)$.

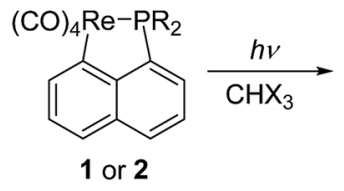<smiles>[Y][R20](=O)(O)c1cccc2ccccc12</smiles>

$7(\mathrm{R}=\mathrm{Ph}, \mathrm{X}=\mathrm{Cl})$

$8\left(\mathrm{R}={ }^{i} \mathrm{Pr}, \mathrm{X}=\mathrm{Cl}\right)$

$9(\mathrm{R}=\mathrm{Ph}, \mathrm{X}=\mathrm{Br})$

$10\left(\mathrm{R}={ }^{i} \mathrm{Pr}, \mathrm{X}=\mathrm{Br}\right)$

reactivity, we similarly treated the P-contained cyclorhenated complex 1 with excess $\mathrm{I}_{2}$ in $\mathrm{CH}_{2} \mathrm{Cl}_{2}$ at room temperature for $24 \mathrm{~h}$, however, no reaction occurred. This result may indicate the higher stability of $\mathbf{1}$ when compared with $\mathrm{N}$-contained analogues. Therefore we decided to try the decyclometalation of 1 or 2 under UV light conditions. A solution of complex 1 or 2 in $\mathrm{CHCl}_{3}$ or $\mathrm{CHBr}_{3}$ was irradiated by UV lamp to give corresponding phosphine-substituted tetracarbonyl rhenium halide 7-10 (Scheme 6). Obviously, the Re-C bond of the five-membered ring in 1 or 2 is cleavaged readily during the photolysis. Complexes 7$\mathbf{1 0}$ were fully characterized by spectroscopic analysis, as well as crystallographic analysis for $\mathbf{9}$. The molecular structure of $\mathbf{9}$ was shown in Fig. 3, with selected bond lengths and angles. Pseudooctahedral geometry is observed around the Re atom. The bromine and the (1-naphthyl)diphenyl phosphine groups are cis to each other. The $\operatorname{Re}(1)-\mathrm{P}(1)$ bond length is 2.5016(12) $\AA$, longer than that $(2.4413(9) \AA)$ in five-membered cyclorhenated structure of 1 , which could be attributed to nonbonding interactions between the phosphine and $\mathrm{Re}(\mathrm{CO})_{4} \mathrm{Br}$ units.

Besides, for further comparison of reactivity, we also performed the photolysis of $\mathbf{1}$ with $\mathrm{CF}_{3} \mathrm{COOH}$. After a solution of $\mathbf{1}$

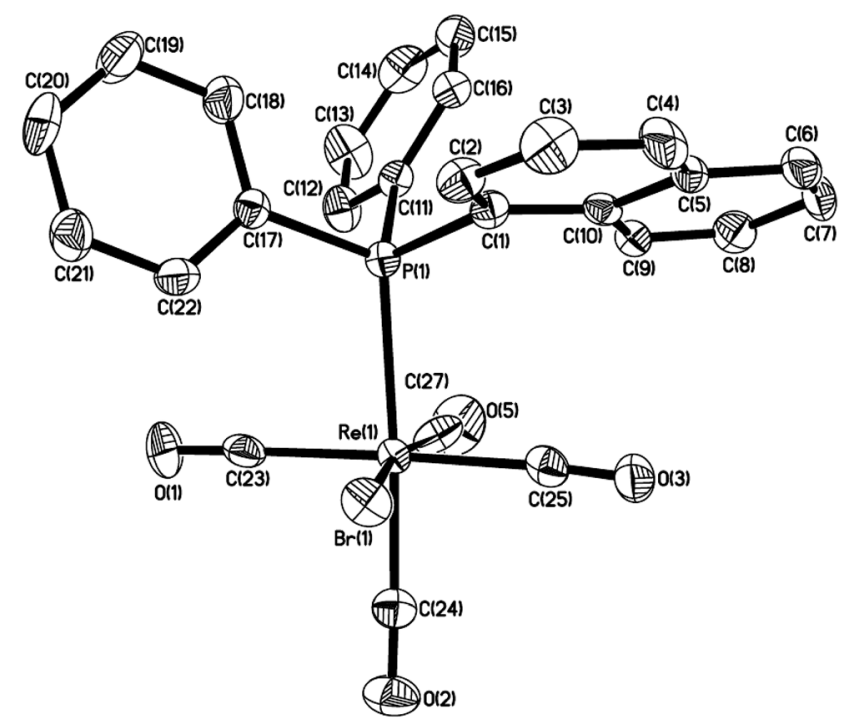

Fig. 3 Thermal ellipsoid drawing of 9 showing the labeling scheme and $50 \%$ probability ellipsoids; hydrogens are omitted for clarity. Selected bond lengths $[\AA]$ and angles $\left[{ }^{\circ}\right]$ are $\operatorname{Re}(1)-P(1) 2.5016(12)$, $\operatorname{Re}(1)-\operatorname{Br}(1)$ 2.620(2), $\operatorname{Re}(1)-C(23) 2.016(6), \operatorname{Re}(1)-C(24)$ 1.968(5), $\operatorname{Re}(1)-$ $C(25)$ 1.997(6), $\operatorname{Re}(1)-C(27) 1.952(8), \angle P(1)-\operatorname{Re}(1)-C(24)$ 176.40(16), $\angle C(23)-\operatorname{Re}(1)-C(25) 178.0(2), \angle B r(1)-\operatorname{Re}(1)-C(27) 169.1(6)$. 


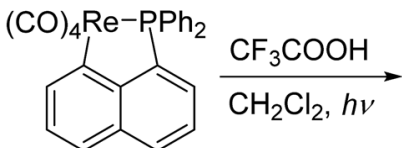

1

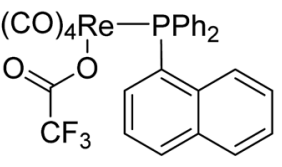

11
Scheme 7 Photolysis of 1 with $\mathrm{CF}_{3} \mathrm{COOH}$ in $\mathrm{CH}_{2} \mathrm{Cl}_{2}$.

with $\mathrm{CF}_{3} \mathrm{COOH}$ in $\mathrm{CH}_{2} \mathrm{Cl}_{2}$ was irradiated for $8 \mathrm{~h}$, a white product $\mathbf{1 1}$ was obtained in moderate yield (Scheme 7). Complexes $\mathbf{1 1}$ was fully characterized by spectroscopic and crystallographic analysis. The molecular structure of $\mathbf{1 1}$ was shown in Fig. 4. Similarly to $\mathbf{9}$, the pseudooctahedral geometry is observed around the Re atom. The carboxylate $\left(\mathrm{CF}_{3} \mathrm{CO}_{2}\right)$ and the (1naphthyl)diphenyl phosphine groups are cis to each other. The $\operatorname{Re}(1)-\mathrm{P}(1)$ bond length is 2.494(2) $\AA$, close to (2.5016(12) $\mathrm{A})$ that in 9, but also longer than that (2.4413(9) $\AA$ ) in five-membered ring structure of $\mathbf{1}$. The formation of $\mathbf{1 1}$ indicates that the reactivity of $\mathbf{1}$ is similar to that of $\mathrm{N}$-contained analogues when reacted with $\mathrm{CF}_{3} \mathrm{CO}_{2} \mathrm{H}^{14}$

\section{Photochemical reactions of 1-3 with aryl halides in benzene}

We have reported the photochemical reactions of cyclopentadienylrheniumtricarbonyls $\left[\left(\eta^{5}-\mathrm{C}_{5} \mathrm{R}_{5}\right) \mathrm{Re}(\mathrm{CO})_{3}\right](\mathrm{R}=\mathrm{Me}$ or $\mathrm{H})$, or doubly-bridged biscyclopentadienyl dirhenium carbonyls with aryl halides in benzene, which generate biphenyl almost stoichiometrically, as well as the corresponding rhenium dicarbonyl products..$^{15}$ In order to expand the reaction scope of this type, we used cyclometalated rhenium complexes 1-3 as starting materials and tried the similar photochemical reactions with aryl halides in benzene.

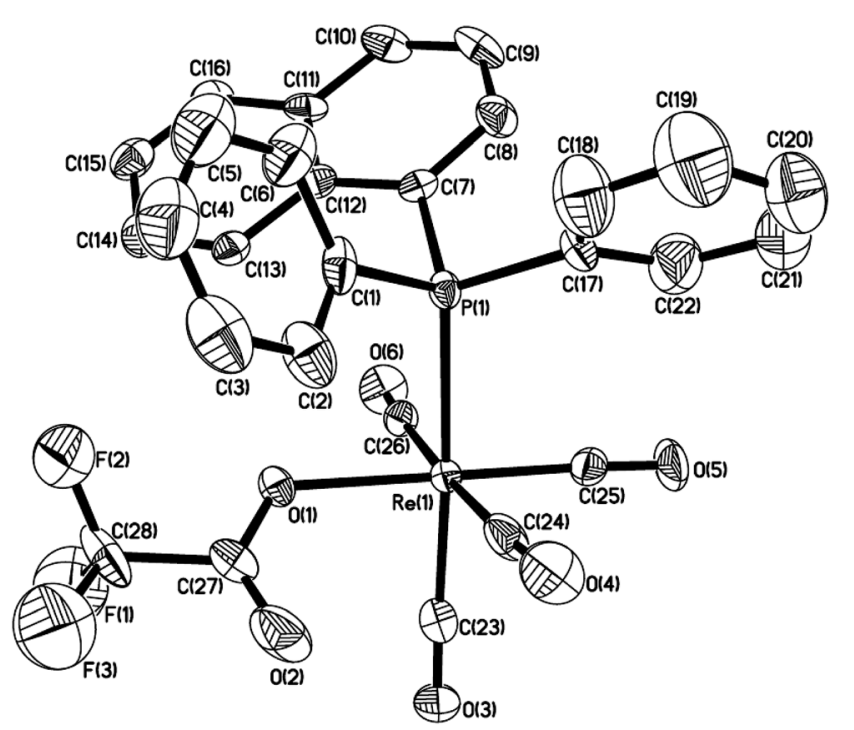

Fig. 4 Thermal ellipsoid drawing of 11 showing the labeling scheme and $50 \%$ probability ellipsoids; hydrogens are omitted for clarity. Selected bond lengths $[\AA]]$ and angles $\left[{ }^{\circ}\right]$ are $\operatorname{Re}(1)-P(1) 2.494(2), \operatorname{Re}(1)-$ $\mathrm{O}(1) 2.145(5), \operatorname{Re}(1)-C(23) 1.971(9), \operatorname{Re}(1)-C(24) 2.007(8), \operatorname{Re}(1)-C(25)$ 1.915(8), $\operatorname{Re}(1)-C(26) 2.003(8), \angle P(1)-\operatorname{Re}(1)-C(23) 174.4(2), \angle C(24)-$ $\operatorname{Re}(1)-C(26) 176.4(3), \quad \angle O(1)-\operatorname{Re}(1)-C(25) 176.0(3)$.
Photolysis of 1-3 with 5 equiv. of bromobenzene in benzene under $\mathrm{N}_{2}$ for $1-4.5 \mathrm{~h}$ produced a yellow solution. After removal of the solvent under vacuum, the residue was carefully separated in air by column chromatography on silica gel, and afforded the corresponding phosphine-substituted tetracarbonyl rhenium bromides $\mathbf{9 , 1 0}$, and $\mathbf{1 2}$ (Scheme 8). Besides, the reactions also stoichiometrically produced biphenyl (9298\%, entries 1-3 in Table 1). Further activation of C-I bond and the relatively inert $\mathrm{C}-\mathrm{Cl}$ bond by $\mathbf{1}$ was also conducted by photolysis of $\mathbf{1}$ with iodobenzene and chlorobenzene in benzene, which similarly provided the corresponding phosphine-substituted tetracarbonyl rhenium iodide (13) and chloride (7), as well as the biphenyl (Scheme 8) (entries 4-5, Table 1). To expand the scope of the substrates, photolysis of several para-substituted aryl halides with $\mathbf{1}$ were examined, and the reactions gave similarly the rhenium halides $\mathbf{7}$ or $\mathbf{9}$, and the para-substituted biphenyl, no matter when the substituent is an electron-donating $(\mathrm{MeO})$ or electron-withdrawing $\left(\mathrm{CF}_{3}, \mathrm{CH}_{3} \mathrm{CO}\right)$ group (entries 6-10, Table 1). Next, the source of the biphenyl was investigated. Photolysis of $\mathbf{1}$ with $p$-bromoanisole in benzene- $d 6$ generated the 4-methoxybiphenyl- $d 5 \quad\left(p-\mathrm{CH}_{3} \mathrm{O}-\right.$ $\mathrm{C}_{6} \mathrm{H}_{4}-\mathrm{C}_{6} \mathrm{D}_{5}$ ), completely no biphenyl or $4,4^{\prime}$-dimethoxybiphenyl were observed. It is revealed that the $p-\mathrm{CH}_{3} \mathrm{O}-\mathrm{C}_{6} \mathrm{H}_{4}$ and $\mathrm{C}_{6} \mathrm{D}_{5}$ moieties in the resulting substituted biphenyl come from $p$ bromoanisole and solvent benzene- $d 6$, respectively.

\section{Rhenium-catalyzed direct arylation of arenes with aryl halides}

On the basis of the photochemical reactions described above, we considered if the products, the phosphine-substituted tetracarbonyl rhenium halides, could revert to the original cyclometalated rhenium complexes 1-3, then a catalytic cycle would be created. Generally, cyclometalation of the ligand-substituted rhenium halides could be realized in the presence of base. $\mathrm{Lu}$ has reported a cyclometalation reaction of $\operatorname{ReBr}(\mathrm{CO})_{4}\left[^{-}\right.$ $\mathrm{C}(\mathrm{NHR})(\mathrm{NHPh})]\left(\mathrm{R}={ }^{\mathrm{i}} \mathrm{Pr}\right.$, or $\left.\mathrm{Pr}\right)$ with $\mathrm{Et}_{2} \mathrm{NH}$ in $\mathrm{CH}_{2} \mathrm{Cl}_{2}$ to give $\operatorname{Re}(\mathrm{CO})_{4}\left[\eta^{2}-\mathrm{C}(\mathrm{NHR})(\mathrm{NHPh})\right] .^{14}$ For optimization of reaction conditions, the cross-coupling of 4-bromoanisole with benzene was selected as the model reaction. The reactions were carried out with $0.5 \mathrm{~mol} \%$ of cyclometalated rhenium complex 1 in benzene and different bases were used. Only $\mathrm{NaOH}$ as the base afforded the biphenyl product in moderate yield (59\%, entry 1 of Table 2), whereas other tested bases such as $\mathrm{K}_{2} \mathrm{CO}_{3}$, KOAc, ${ }^{t} \mathrm{BuOK}$, and pyrrolidine gave rise to lower yields $(26-50 \%$, entries 2-5). Other two cyclometalated rhenium complexes 2 and 3 as catalysts were also screened under the optimized conditions, complex 2 afforded slightly higher yield (68\%, entry 6) than $\mathbf{1}$, while complex 3 gave much lower yield (26\%, entry 7$)$. To expand the scope of the substrates, other aryl bromides,

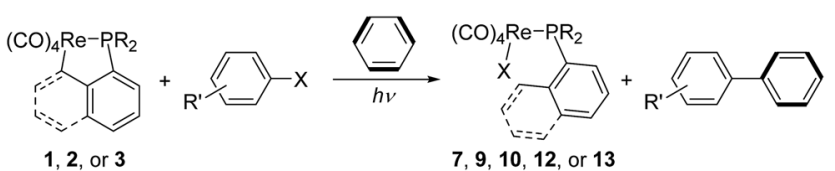

Scheme 8 Photochemical reactions of 1-3 with aryl halides in benzene. 
Table 1 Photochemical reactions of 1-3 with aryl halides in benzene ${ }^{a}$

\begin{tabular}{|c|c|c|c|c|c|c|c|}
\hline Entry & $\mathrm{Re}$ & $\mathrm{R}^{\prime}$ & $\mathrm{X}$ & $t[\mathrm{~h}]$ & Product $^{b}$ & Yield $^{c}[\%]$ & Re prod. \\
\hline 1 & 1 & $\mathrm{H}$ & $\mathrm{Br}$ & 1 & Biphenyl & $>98$ & 9 \\
\hline 2 & 2 & $\mathrm{H}$ & $\mathrm{Br}$ & 1 & Biphenyl & 95 & 10 \\
\hline 4 & 1 & $\mathrm{H}$ & $\mathrm{Cl}$ & 4 & Biphenyl & 85 & 7 \\
\hline 5 & 1 & $\mathrm{H}$ & I & 1 & Biphenyl & 92 & 13 \\
\hline 6 & 1 & $p$-MeO & $\mathrm{Br}$ & 4 & $p$-MeO-biphenyl & 98 & 9 \\
\hline 9 & 1 & $p-\mathrm{MeO}$ & $\mathrm{Cl}$ & 4.5 & $p$-MeO-biphenyl & 90 & 7 \\
\hline 10 & 1 & $p-\mathrm{CF}_{3}$ & $\mathrm{Cl}$ & 1.5 & $p-\mathrm{CF}_{3}$-biphenyl & 87 & 7 \\
\hline
\end{tabular}

${ }^{a}$ Reaction conditions: irradiation of 1-3 $(0.10 \mathrm{mmol})$ and $\mathrm{Ar}-\mathrm{X}(0.50 \mathrm{mmol})$ in $10 \mathrm{~mL}$ benzene solvent with a $500 \mathrm{~W}$ high-pressure $\mathrm{Hg}$ lamp $\left(\lambda_{\mathrm{max}}=\right.$ $365 \mathrm{~nm}$ ) in the ice-water bath. ${ }^{b}$ Biphenyl products were isolated by routine silica gel column chromatography, and identified by comparing their respective ${ }^{1} \mathrm{H}$ NMR spectra with authentic samples. ${ }^{c}$ Isolated yield (based on unrecovered 1-3).

Table 2 Rhenium-catalyzed direct arylation of arenes with aryl halides $^{a}$

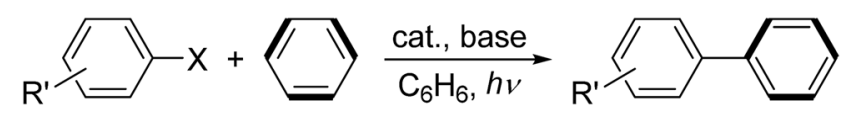

\begin{tabular}{|c|c|c|c|c|c|c|c|}
\hline Entry & Cat & Base & $\mathrm{R}^{\prime}$ & $\mathrm{X}$ & $\begin{array}{l}t \\
{[\mathrm{~h}]}\end{array}$ & Product $^{b}$ & $\begin{array}{l}\text { Yield }^{b, c} \\
{[\%]}\end{array}$ \\
\hline 1 & 1 & $\mathrm{NaOH}$ & $p$-MeO & $\mathrm{Br}$ & 4 & p-MeO-biphenyl & 59 \\
\hline 2 & 1 & $\mathrm{~K}_{2} \mathrm{CO}_{3}$ & $p$-MeO & $\mathrm{Br}$ & 4 & p-MeO-biphenyl & 30 \\
\hline 3 & 1 & KOAc & $p-\mathrm{MeO}$ & $\mathrm{Br}$ & 4 & p-MeO-biphenyl & 26 \\
\hline 4 & 1 & ${ }^{t} \mathrm{BuOK}$ & $p-\mathrm{MeO}$ & $\mathrm{Br}$ & 4 & $p$-MeO-biphenyl & 50 \\
\hline 5 & 1 & Pyrrolidine & $p-\mathrm{MeO}$ & $\mathrm{Br}$ & 6 & $p$-MeO-biphenyl & 29 \\
\hline 6 & 2 & $\mathrm{NaOH}$ & $p-\mathrm{MeO}$ & $\mathrm{Br}$ & 5 & $p$-MeO-biphenyl & 68 \\
\hline 7 & 3 & $\mathrm{NaOH}$ & $p-\mathrm{MeO}$ & $\mathrm{Br}$ & 5 & $p$-MeO-biphenyl & 26 \\
\hline 8 & 1 & $\mathrm{NaOH}$ & $\mathrm{H}$ & $\mathrm{Br}$ & 4 & Biphenyl & 65 \\
\hline 9 & 1 & $\mathrm{NaOH}$ & $p-\mathrm{CF}_{3}$ & $\mathrm{Br}$ & 3 & $p-\mathrm{CF}_{3}$-biphenyl & 60 \\
\hline 10 & 1 & $\mathrm{NaOH}$ & $\mathrm{H}$ & $\mathrm{Cl}$ & 8 & Biphenyl & 26 \\
\hline 11 & 1 & $\mathrm{NaOH}$ & $\mathrm{H}$ & I & 8 & Biphenyl & 35 \\
\hline
\end{tabular}

${ }^{a}$ Reaction conditions: irradiation of 1-3 $(0.01 \mathrm{mmol}), \mathrm{Ar}-\mathrm{X}(2.0 \mathrm{mmol})$, and base $(2.0 \mathrm{mmol})$ in $20 \mathrm{~mL}$ benzene solvent with a $500 \mathrm{~W}$ highpressure $\mathrm{Hg}$ lamp $\left(\lambda_{\max }=365 \mathrm{~nm}\right)$ in the ice-water bath. ${ }^{b}$ Biphenyl products were isolated by routine silica gel column chromatography, and identified by comparing their respective ${ }^{1} \mathrm{H}$ NMR spectra with authentic samples. ${ }^{c}$ Isolated yield (based on unrecovered 1-3).

including bromobenzene, and 4-bromobenzotrifluoride were examined, and the reactions afforded the corresponding biphenyl in yields of $65 \%$ and $60 \%$ (entries 8 and 9). Besides, the substrates chlorobenzene and iodobenzene were also tested using the catalyst 1 , which resulted in lower yields $(26 \%$ and $35 \%$, entries 10 and 11 ).

Unfortunately, rhenium catalysts 1-3 did not show higher activity to direct arylation of arenes with aryl halide under our current conditions. When we performed the photolysis of phosphine-substituted tetracarbonyl rhenium bromide 9 in benzene in the presence of $\mathrm{NaOH}$, the expected cyclometalated rhenium complex 1 was observed, at the same time, we also obtained some free ligand, (1-naphthyl) diphenyl phosphine. Obviously, complex 9 was decomposed partially under UV irradiation, which may explain the moderate catalytic performance of $\mathbf{1}$. Based on the results described above, a plausible catalytic mechanism is tentatively proposed: first, a CO is dissociated from cyclometalated rhodium complexes 1-3 under UV irradiation to give a $16 \mathrm{e}^{-}$ unsaturated species; this is followed by oxidative addition of a $\mathrm{C}-\mathrm{X}$ bond on aryl halides ( $\mathrm{Ph}-\mathrm{X})$ to form the $\mathrm{Re}(\mathrm{III})$ intermediate. In the next step, a radical aromatic substitution that involves the aromatic radical with the solvent benzene might occur to give biphenyl and the corresponding cyclometalated rhenium hydride halide complexes, which undergo reductive elimination and recoordination of $\mathrm{CO}$ to afford the ringopening complexes $(7,9,10,12$, and 13$)$. In the final step, cyclometalation of ring-opening complexes is achieved in the presence of base to generate the catalytic cycle. When we tried to synthesize the Re(III) intermediate to support the mechanism, unfortunately, we did not obtained the expected product either from photolysis of 1-3 in pure $\mathrm{Ph}-\mathrm{X}$ or photolysis of 1-3 and $\mathrm{Ph}-\mathrm{X}$ in cyclohexane.

\section{Summary}

A series of five-membered cyclometalated rhenium complexes (1-5) were synthesized by thermal treatment of aryl-substituted phosphines or phosphinites with $\mathrm{Re}_{2}(\mathrm{CO})_{10}$ in chlorobenzene. The formation of cyclorhenated complexes went through an intramolecular activation of $\mathrm{C}\left(\mathrm{sp}^{2}\right)-\mathrm{H}$ or $\mathrm{C}\left(\mathrm{sp}^{3}\right)-\mathrm{H}$ bond. Competition reaction indicated that the aromatic $\mathrm{C}\left(\mathrm{sp}^{2}\right)-\mathrm{H}$ bond is more likely to be activated than $\mathrm{C}\left(\mathrm{sp}^{3}\right)-\mathrm{H}$ bond under the same conditions. The chemical behavior of the cyclorhenated complexes 1, 2 or 3 has been investigated, including photolysis of 1 or 2 in $\mathrm{CHX}_{3}$, reaction of $\mathbf{1}$ with $\mathrm{CF}_{3} \mathrm{COOH}$, and photolysis of 1-3 with aryl halides in benzene, all of them caused the cleavage of Re-C $\sigma$ bond and then the opening of metallacycle. Some reaction indicated the lower reactivity of the cyclometalated rhenium complexes in this work than that of $\mathrm{N}$ contained cyclorhenated complexes. Besides, complexes 1-3 exhibited moderate catalytic activity on direct arylation of arenes with aryl halides under UV irradiation at a $[\mathrm{Re}]$ : substrate ratio of $1: 200$. 


\section{Experimental}

\section{General considerations}

All reactions were carried out under nitrogen using standard Schlenk and vacuum line techniques; however the workup was carried out in air unless stated otherwise. All solvents were distilled from appropriate drying agents under nitrogen prior to use. ${ }^{1} \mathrm{H}(400 \mathrm{MHz}),{ }^{13} \mathrm{C}\left\{{ }^{1} \mathrm{H}\right\}(100 \mathrm{MHz})$, and ${ }^{31} \mathrm{P}\left\{{ }^{1} \mathrm{H}\right\}(162 \mathrm{MHz})$ NMR spectra were recorded on a Bruker AV400 instrument at room temperature with $\mathrm{CDCl}_{3}$ as solvent. Chemical shifts were recorded in ppm, referenced to residual ${ }^{1} \mathrm{H}$ and ${ }^{13} \mathrm{C}$ signals of the non-deuterated $\mathrm{CDCl}_{3}(\delta 7.26$ and 77.16) as internal standards or to the ${ }^{31} \mathrm{P}$ signal of $\mathrm{PPh}_{3}(\delta-5.65)$ as an external standard. Elemental analyses were performed on a PerkinElmer $240 \mathrm{C}$ analyzer. IR spectra were recorded as $\mathrm{KBr}$ disks on a Nicolet 560 ESP FTIR spectrometer. $\operatorname{Re}_{2}(\mathrm{CO})_{10}$ was purchased from Strem without further purification; the ligands diisopropyl(1-naphthyl) phosphine, ${ }^{\mathbf{1 6}}$ (1-naphthyl)diphenyl phosphine, ${ }^{\mathbf{1 6}}$ diisopropyl(o-methylphenyl) phosphine, ${ }^{17}$ diisopropyl(2-methylnaphthyl) phosphine, ${ }^{17} \quad o$-methylphenyl diisopropylphosphinite, ${ }^{18}$ and 1-naphthyl diisopropylphosphinite ${ }^{18}$ were prepared by literature methods.

\section{General procedure for the reactions of $\operatorname{Re}_{2}(\mathrm{CO})_{10}$ with phosphines or phosphinites in chlorobenzene}

A mixture of $\operatorname{Re}_{2}(\mathrm{CO})_{10}(0.05 \mathrm{mmol})$ and phosphine or phosphinite (2.0 equiv.) in chlorobenzene $(10 \mathrm{~mL})$ was refluxed for $10 \mathrm{~h}$ and then concentrated under vacuum, the residue was chromatographed on a silica gel column with a mixture of petrol ether $/ \mathrm{CH}_{2} \mathrm{Cl}_{2}$ as the eluent. The products were recrystallized from $n$-hexane $/ \mathrm{CH}_{2} \mathrm{Cl}_{2}(1: 1)$ at $-10{ }^{\circ} \mathrm{C}$ to afford 1-6 as colorless crystals in yields of $45-85 \%$.

1, (82\% yield). ${ }^{1} \mathrm{H}$ NMR: $\delta 8.21(\mathrm{~d}, J=6.0 \mathrm{~Hz}, 1 \mathrm{H}), 7.95(\mathrm{~d}, J=$ $8.0 \mathrm{~Hz}, 1 \mathrm{H}), 7.68$ (d, $J=8.4 \mathrm{~Hz}, 1 \mathrm{H}), 7.60$ (m, 1H), 7.55-7.49 (m, $5 \mathrm{H}), 7.44(\mathrm{~m}, 6 \mathrm{H}), 7.35(\mathrm{~m}, 1 \mathrm{H}) .{ }^{13} \mathrm{C}\left\{{ }^{1} \mathrm{H}\right\}$ NMR: $\delta$ 189.1, 189.0, $152.4,149.7,144.3,138.2,134.7,134.3,132.8$, 132.6, 132.5, 131.6, 130.8, 129.0, 128.9, 127.9, 124.6, 123.9. ${ }^{31} \mathrm{P}\left\{{ }^{1} \mathrm{H}\right\}$ NMR: $\delta$ 26.4. IR ( $\left.\nu_{\mathrm{CO}}\right): 2084(\mathrm{~m}), 1998$ (s), 1976 (s), 1955 (s), 1929 (s) $\mathrm{cm}^{-1}$. Anal. calcd for $\mathrm{C}_{26} \mathrm{H}_{16} \mathrm{O}_{4} \mathrm{PRe}$ C, 51.23; H, 2.65. Found: $\mathrm{C}$, $51.37 ; \mathrm{H}, 2.42$.

2, (85\% yield). ${ }^{1} \mathrm{H}$ NMR: $\delta 8.16(\mathrm{~m}, 1 \mathrm{H}), 7.85(\mathrm{~m}, 1 \mathrm{H}), 7.58(\mathrm{~m}$, 2H), $7.43(\mathrm{~m}, 1 \mathrm{H}), 7.28$ (m, 1H), 2.58 (m, 2H, CH), 1.33 (dd, 6H, $\mathrm{CH}_{3}$ ), 1.04 (dd, 6H, $\mathrm{CH}_{3}$ ). ${ }^{13} \mathrm{C}\left\{{ }^{1} \mathrm{H}\right\}$ NMR: $\delta$ 190.2, 189.8, 189.7, $189.4,152.5,149.7,143.9$, 138.8, 134.5, 132.2, 128.1, 127.5, 124.1, 123.8, 29.7, 29.5, 20.3, 20.1. ${ }^{31} \mathrm{P}\left\{{ }^{1} \mathrm{H}\right\}$ NMR: $\delta$ 49.2. IR $\left(\nu_{\mathrm{CO}}\right)$ : 2076 (w), 1970 (s), 1925 (s) cm $\mathrm{cm}^{-1}$. Anal. calcd for $\mathrm{C}_{20} \mathrm{H}_{20} \mathrm{O}_{4} \mathrm{PRe}$ : C, 44.36; H, 3.72. Found: C, 44.49; H, 3.48.

3, (56\% yield). ${ }^{1} \mathrm{H}$ NMR: $\delta 7.38(\mathrm{~m}, 1 \mathrm{H}), 7.27-7.21(\mathrm{~m}, 2 \mathrm{H})$, $7.04(\mathrm{~m}, 1 \mathrm{H}), 2.50\left(\mathrm{~m}, 2 \mathrm{H}, \mathrm{CH}_{2}\right), 2.49(\mathrm{~m}, 2 \mathrm{H}, \mathrm{CH}), 1.20$ (dd, $6 \mathrm{H}$, $\mathrm{CH}_{3}$ ), 1.05 (dd, 6H, $\mathrm{CH}_{3}$ ). ${ }^{13} \mathrm{C}\left\{{ }^{1} \mathrm{H}\right\}$ NMR: $\delta$ 191.1, 190.3, 189.2, $162.8,134.3$, 131.4, 130.2, 129.5, 123.9, 77.4, 28.1, 27.8, 19.3, 18.9. ${ }^{31} \mathrm{P}\left\{{ }^{1} \mathrm{H}\right\}$ NMR: $\delta$ 48.8. IR ( $\left.\nu_{\mathrm{CO}}\right): 2073$ (s), 1986 (s), 1931 (s) $\mathrm{cm}^{-1}$. Anal. calcd for $\mathrm{C}_{17} \mathrm{H}_{20} \mathrm{O}_{4} \mathrm{PRe}$ C, 40.39; $\mathrm{H}, 3.99$. Found: $\mathrm{C}$, 40.74; H, 3.75 .

4, (63\% yield). ${ }^{1} \mathrm{H}$ NMR: $\delta 8.18(\mathrm{~m}, 1 \mathrm{H}), 7.74(\mathrm{~m}, 1 \mathrm{H}), 7.54(\mathrm{~m}$, $1 \mathrm{H}), 7.21(\mathrm{~m}, 2 \mathrm{H}), 2.91(\mathrm{~m}, 2 \mathrm{H}, \mathrm{CH}), 2.71$ (d, 3H, $\left.\mathrm{CH}_{3}\right), 1.49$ (dd,
6H, $\mathrm{CH}_{3}$ ), 0.83 (dd, 6H, $\left.\mathrm{CH}_{3}\right) .{ }^{31} \mathrm{P}\left\{{ }^{1} \mathrm{H}\right\} \mathrm{NMR}: \delta$ 64.0. IR $\left(\nu_{\mathrm{CO}}\right): 2074$ (s), 1980 (s), 1927 (s) $\mathrm{cm}^{-1}$. Anal. calcd for $\mathrm{C}_{21} \mathrm{H}_{22} \mathrm{O}_{4} \mathrm{PRe}$ C, 45.40; H, 3.99. Found: C, 45.27; H, 3.83.

5, (45\% yield). ${ }^{1} \mathrm{H}$ NMR: $\delta 7.55(\mathrm{~d}, J=7.2 \mathrm{~Hz}, 1 \mathrm{H}), 6.84(\mathrm{~d}, J=$ $7.2 \mathrm{~Hz}, 1 \mathrm{H}), 6.71(\mathrm{t}, J=7.2 \mathrm{~Hz}, 1 \mathrm{H}), 2.53(\mathrm{~m}, 2 \mathrm{H}, \mathrm{CH}), 2.25(\mathrm{~s}, 3 \mathrm{H}$, $\mathrm{CH}_{3}$ ), 1.30 (dd, 6H, $\mathrm{CH}_{3}$ ), 1.21 (dd, 6H, $\mathrm{CH}_{3}$ ). ${ }^{31} \mathrm{P}\left\{{ }^{1} \mathrm{H}\right\}$ NMR: $\delta$ 158.3. IR ( $\left.\nu_{\mathrm{CO}}\right): 2080(\mathrm{~s}), 1982(\mathrm{~s}), 1955(\mathrm{~s}) \mathrm{cm}^{-1}$. Anal. calcd for $\mathrm{C}_{17} \mathrm{H}_{20} \mathrm{O}_{5}$ PRe: C, 39.15; H, 3.87. Found: C, 39.43; H, 3.81.

6, (66\% yield). ${ }^{1} \mathrm{H}$ NMR: $\delta 8.20(\mathrm{~m}, 2 \mathrm{H}), 7.80(\mathrm{~m}, 2 \mathrm{H}), 7.58(\mathrm{~m}$, 2H), $7.48(\mathrm{~m}, 4 \mathrm{H}), 7.34(\mathrm{~m}, 2 \mathrm{H}), 7.15(\mathrm{~m}, 2 \mathrm{H}), 2.85(\mathrm{~m}, 4 \mathrm{H}, \mathrm{CH})$, 1.43-1.31 (m, 24H, $\left.\mathrm{CH}_{3}\right) .{ }^{13} \mathrm{C}\left\{{ }^{1} \mathrm{H}\right\}$ NMR: $\delta$ 200.2, 135.2, 128.0, 127.3, 126.6, 125.9, 125.4, 123.7, 122.2, 120.2, 115.8, 36.9, 32.8, 18.8, 18.5. ${ }^{31} \mathrm{P}\left\{{ }^{1} \mathrm{H}\right\}$ NMR: $\delta$ 159.0. IR $\left(\nu_{\text {CO }}\right): 1965$ (s), $1933(\mathrm{~s}), 1897$ (s) $\mathrm{cm}^{-1}$. Anal. calcd for $\mathrm{C}_{40} \mathrm{H}_{42} \mathrm{O}_{10} \mathrm{P}_{2} \mathrm{Re}_{2}$ : C, 43.01; H, 3.79. Found: C, 42.85; H, 3.62.

\section{General procedure for photolysis of 1 or 2 in $\mathrm{CHX}_{3}(\mathrm{X}=\mathrm{Cl}, \mathrm{Br})$}

A solution of 1 or $2(0.05 \mathrm{mmol})$ in $\mathrm{CHX}_{3}(5 \mathrm{~mL})$ was irradiated by UV light for $8 \mathrm{~h}$, then the solvent was removed under vacuum, the residue was chromatographed on a silica gel column with a mixture of petrol ether $/ \mathrm{CH}_{2} \mathrm{Cl}_{2}$ as the eluent. The products were recrystallized from $n$-hexane $/ \mathrm{CH}_{2} \mathrm{Cl}_{2}(1: 1)$ at $-10{ }^{\circ} \mathrm{C}$ to afford 7-10 as colorless crystals in yields of $54-81 \%$.

7, (62\% yield). ${ }^{1} \mathrm{H}$ NMR: $\delta 8.01(\mathrm{~m}, 1 \mathrm{H}), 7.96(\mathrm{~m}, 2 \mathrm{H}), 7.78-$ $7.73(\mathrm{~m}, 4 \mathrm{H}), 7.54(\mathrm{~m}, 1 \mathrm{H}), 7.50-7.39(\mathrm{~m}, 8 \mathrm{H}), 7.36(\mathrm{~m}, 1 \mathrm{H}) .{ }^{31} \mathrm{P}$ $\left\{{ }^{1} \mathrm{H}\right\}$ NMR: $\delta$ 3.1. IR $\left(\nu_{\mathrm{CO}}\right): 2105(\mathrm{~m}), 1997(\mathrm{~s}), 1943(\mathrm{~s}), 1896(\mathrm{~m})$ $\mathrm{cm}^{-1}$. Anal. calcd for $\mathrm{C}_{26} \mathrm{H}_{17} \mathrm{ClO}_{4} \mathrm{PRe}$ C, 48.34; H, 2.65. Found: $\mathrm{C}, 48.57 ; \mathrm{H}, 2.49$.

8, (54\% yield). ${ }^{1} \mathrm{H}$ NMR: $\delta 8.42(\mathrm{~d}, J=8.4 \mathrm{~Hz}, 1 \mathrm{H}), 7.94(\mathrm{~d}, J=$ $8.0 \mathrm{~Hz}, 2 \mathrm{H}), 7.73(\mathrm{~m}, \mathrm{qH}), 7.65(\mathrm{~m}, 1 \mathrm{H}), 7.60-7.52(\mathrm{~m}, 2 \mathrm{H}), 3.39$ (m, 2H, CH), 1.58 (dd, 6H, $\mathrm{CH}_{3}$ ), 1.38 (dd, 6H, $\left.\mathrm{CH}_{3}\right) .{ }^{31} \mathrm{P}\left\{{ }^{1} \mathrm{H}\right\}$ NMR: $\delta$ 12.4. IR ( $\left.\nu_{\mathrm{CO}}\right): 2105(\mathrm{~m}), 2011(\mathrm{~s}), 1922(\mathrm{~s}) \mathrm{cm}^{-1}$. Anal. calcd for $\mathrm{C}_{20} \mathrm{H}_{21} \mathrm{ClO}_{4}$ PRe: $\mathrm{C}, 41.56 ; \mathrm{H}, 3.66$. Found: $\mathrm{C}, 41.35 ; \mathrm{H}$, 3.71 .

9, (81\% yield). ${ }^{1} \mathrm{H}$ NMR: $\delta 8.00(\mathrm{~m}, 1 \mathrm{H}), 7.95(\mathrm{~m}, 2 \mathrm{H}), 7.76(\mathrm{~m}$, 4H), $7.53(\mathrm{~m}, 1 \mathrm{H}), 7.48-7.38(\mathrm{~m}, 8 \mathrm{H}), 7.35(\mathrm{~m}, 1 \mathrm{H}) .{ }^{31} \mathrm{P}\left\{{ }^{1} \mathrm{H}\right\}$ NMR: $\delta-0.3$. IR $\left(\nu_{\mathrm{CO}}\right): 2105(\mathrm{~s}), 2012(\mathrm{~s}), 1947$ (s), $1921(\mathrm{~s}) \mathrm{cm}^{-1}$. Anal. calcd for $\mathrm{C}_{26} \mathrm{H}_{17} \mathrm{BrO}_{4} \mathrm{PRe}$ C, 45.23; H, 2.48. Found: C, 45.18; $\mathrm{H}$, 2.36 .

10, (78\% yield). ${ }^{1} \mathrm{H}$ NMR: $\delta 8.38(\mathrm{~m}, 1 \mathrm{H}), 7.94(\mathrm{~m}, 2 \mathrm{H}), 7.73$ (m, 1H), $7.65(\mathrm{~m}, 1 \mathrm{H}), 7.60-7.53(\mathrm{~m}, 2 \mathrm{H}), 3.44(\mathrm{~m}, 2 \mathrm{H}, \mathrm{CH}), 1.58$ (dd, 6H, $\left.\mathrm{CH}_{3}\right), 1.38$ (dd, 6H, $\left.\mathrm{CH}_{3}\right) .{ }^{31} \mathrm{P}\left\{{ }^{1} \mathrm{H}\right\}$ NMR: $\delta$ 7.3. IR $\left(\nu_{\mathrm{CO}}\right)$ : 2106 (s), 2010 (s), 1919 (s) $\mathrm{cm}^{-1}$. Anal. calcd for $\mathrm{C}_{20} \mathrm{H}_{21} \mathrm{BrO}_{4} \mathrm{PRe}$ : C, 38.59; H, 3.40. Found: C, 38.43; H, 3.42.

\section{Reaction of 1 with $\mathrm{CF}_{3} \mathrm{COOH}$}

A solution of $1(0.05 \mathrm{mmol})$ in $\mathrm{CH}_{2} \mathrm{Cl}_{2}(5 \mathrm{~mL})$ was treated with excess $\mathrm{CF}_{3} \mathrm{COOH}(0.3 \mathrm{mmol})$. The mixture was stirred for $24 \mathrm{~h}$ at room temperature. The solvent was removed under vacuum, and the residue was chromatographed on a silica gel column with a mixture of petrol ether $/ \mathrm{CH}_{2} \mathrm{Cl}_{2}$ as the eluent. The product was recrystallized from $n$-hexane $/ \mathrm{CH}_{2} \mathrm{Cl}_{2}(1: 1)$ at $-10{ }^{\circ} \mathrm{C}$ to afford 11 as colorless crystals in $48 \%$ yield.

$11{ }^{1} \mathrm{H}$ NMR: $\delta 8.03(\mathrm{~d}, J=8.4 \mathrm{~Hz}, 1 \mathrm{H}), 7.97(\mathrm{~d}, J=8.0 \mathrm{~Hz}, 1 \mathrm{H})$, $7.92(\mathrm{~d}, J=8.8 \mathrm{~Hz}, 1 \mathrm{H}), 7.56-7.41(\mathrm{~m}, 12 \mathrm{H}), 7.38(\mathrm{~d}, J=8.8 \mathrm{~Hz}$, 1H), $7.34(\mathrm{~m}, 1 \mathrm{H}) .{ }^{31} \mathrm{P}\left\{{ }^{1} \mathrm{H}\right\}$ NMR: $\delta$ 9.8. IR $\left(\nu_{\mathrm{CO}}\right): 2106(\mathrm{~s}), 1998(\mathrm{~s})$, 
Table 3 Crystal data and summary of X-ray data collection for 1, 6, 9, and 11

\begin{tabular}{|c|c|c|c|c|}
\hline & 1 & 6 & 9 & 11 \\
\hline Formula & $\mathrm{C}_{26} \mathrm{H}_{16} \mathrm{O}_{4} \mathrm{PRe}$ & $\mathrm{C}_{20} \mathrm{H}_{21} \mathrm{O}_{5} \mathrm{PRe}$ & $\mathrm{C}_{26} \mathrm{H}_{17} \mathrm{BrO}_{4} \mathrm{PRe}$ & $\mathrm{C}_{28} \mathrm{H}_{17} \mathrm{~F}_{3} \mathrm{O}_{6} \mathrm{PRe}$ \\
\hline fw & 609.56 & 558.54 & 690.47 & 723.58 \\
\hline$T(\mathrm{~K})$ & $173.00(10)$ & $296(2)$ & $173.00(10)$ & $154.5(9)$ \\
\hline Cryst syst & Triclinic & Orthorhombic & Triclinic & Monoclinic \\
\hline Space group & $\mathrm{P} \overline{1}$ & $F d d 2$ & $\mathrm{P} \overline{1}$ & $P 2_{1} / c$ \\
\hline$a(\AA)$ & $11.9989(3)$ & $24.564(3)$ & $9.9390(5)$ & $24.3119(9)$ \\
\hline$b(\AA)$ & $14.4984(3)$ & $42.547(5)$ & $11.0789(5)$ & $11.3315(3)$ \\
\hline$c(\AA)$ & $14.8134(4)$ & $7.7934(8)$ & $11.2433(6)$ & $19.6695(6)$ \\
\hline$\alpha(\mathrm{deg})$ & $64.239(2)$ & 90 & $94.119(4)$ & 90 \\
\hline$\beta$ (deg) & $84.8034(19)$ & 90 & $97.332(4)$ & $98.995(3)$ \\
\hline$\gamma(\mathrm{deg})$ & $74.8834(19)$ & 90 & $99.066(4)$ & 90 \\
\hline$V\left(\AA^{3}\right)$ & $2239.82(10)$ & $8145.1(15)$ & $1207.22(10)$ & $5352.1(3)$ \\
\hline$Z$ & 4 & 16 & 2 & 8 \\
\hline$D_{\text {calc }}\left(\mathrm{g} \mathrm{cm}^{-3}\right)$ & 1.808 & 1.822 & 1.900 & 1.796 \\
\hline$\mu\left(\mathrm{mm}^{-1}\right)$ & 11.544 & 6.073 & 6.784 & 4.662 \\
\hline$F(000)$ & 1176.0 & 4336 & 660.0 & 2800.0 \\
\hline Cryst size (mm) & $0.20 \times 0.18 \times 0.15$ & $0.22 \times 0.21 \times 0.20$ & $0.25 \times 0.15 \times 0.14$ & $0.25 \times 0.24 \times 0.2$ \\
\hline Max. $2 \theta$ (deg) & 148.728 & 53.414 & 50.018 & 50.02 \\
\hline No. of reflns collected & 16330 & 13167 & 7610 & 45685 \\
\hline No. of indep reflns $/ R_{\text {int }}$ & $8839 / 0.0273$ & $4177 / 0.0346$ & $4240 / 0.0407$ & $9416 / 0.0564$ \\
\hline No. of params & 577 & 254 & 320 & 703 \\
\hline Goodness-of-fit on $F^{2}$ & 1.061 & 1.001 & 0.958 & 1.087 \\
\hline$R_{1}, \mathrm{w} R_{2}[I>2 \sigma(I)]$ & $0.0294,0.0764$ & $0.0245,0.0435$ & $0.0329,0.0571$ & $0.0487,0.1086$ \\
\hline$R_{1}, \mathrm{w} R_{2}$ (all data) & $0.0313,0.0780$ & $0.0295,0.0453$ & $0.0394,0.0608$ & $0.0563,0.1129$ \\
\hline Largest diff peak and hole $\left(\mathrm{e}^{\mathrm{A}}{ }^{-3}\right)$ & $1.88,-0.99$ & $0.578,-0.298$ & $1.16,-1.42$ & $1.92,-1.43$ \\
\hline
\end{tabular}

1960 (s), 1691 (s) $\mathrm{cm}^{-1}$. Anal. calcd for $\mathrm{C}_{28} \mathrm{H}_{17} \mathrm{~F}_{3} \mathrm{O}_{6} \mathrm{PRe}$ C, 46.48; H, 2.37. Found: C, 46.63; H, 2.45.

\section{General procedure for photolysis of 1-3 with aryl halides in $\mathrm{C}_{6} \mathrm{H}_{6}$}

A solution of 1-3 (0.05 mmol) and aryl halides $(0.25 \mathrm{mmol})$ in dry benzene $(10 \mathrm{~mL})$ in nitrogen flushed quartz tube was additionally degassed by bubbling nitrogen thru for 5 min. After irradiation for 1-4.5 $\mathrm{h}$ in the ice-water bath, the solvent was removed under the reduced pressure. The residue was chromatographed in air on silica gel using petroleum ether- $\mathrm{CH}_{2} \mathrm{Cl}_{2}$ mixture as eluent. The first band (colorless) afforded the corresponding biphenyl as white solids (80-98\%). The second band (colorless) gave corresponding phosphine-substituted tetracarbonyl rhenium halides $(7,9,10,12$, and 13).

12, (32\% yield). ${ }^{1} \mathrm{H}$ NMR: $\delta 7.46(\mathrm{~m}, 1 \mathrm{H}), 7.32(\mathrm{~m}, 3 \mathrm{H}), 3.27$ (m, 2H, CH), $2.60\left(\mathrm{~s}, 3 \mathrm{H}, \mathrm{CH}_{3}\right), 1.58\left(\mathrm{dd}, 6 \mathrm{H}, \mathrm{CH}_{3}\right), 1.37$ (dd, 6H, $\left.\mathrm{CH}_{3}\right) .{ }^{31} \mathrm{P}\left\{{ }^{1} \mathrm{H}\right\}$ NMR: $\delta$ 9.8. IR $\left(\nu_{\mathrm{CO}}\right): 2102(\mathrm{~s}), 2018(\mathrm{~s}), 1980(\mathrm{~s})$, 1938 (s) $\mathrm{cm}^{-1}$. Anal. calcd for $\mathrm{C}_{17} \mathrm{H}_{21} \mathrm{BrO}_{4} \mathrm{PRe}$ C, 34.82 ; $\mathrm{H}, 3.61$. Found: C, 35.13; H, 3.55.

13, (53\% yield). ${ }^{1} \mathrm{H}$ NMR: $\delta 8.01-7.92(\mathrm{~m}, 3 \mathrm{H}), 7.79-7.74(\mathrm{~m}$, $4 \mathrm{H}), 7.53(\mathrm{~m}, 1 \mathrm{H}), 7.49-7.34(\mathrm{~m}, 9 \mathrm{H}) .{ }^{31} \mathrm{P}\left\{{ }^{1} \mathrm{H}\right\}$ NMR: $\delta-6.2$. IR $\left(\nu_{\mathrm{CO}}\right): 2099$ (s), 1992 (br), 1942 (s) $\mathrm{cm}^{-1}$. Anal. calcd for $\mathrm{C}_{26^{-}}$ $\mathrm{H}_{17} \mathrm{IO}_{4} \mathrm{PRe}: \mathrm{C}, 42.34 ; \mathrm{H}, 2.32$. Found: C, 42.47; H, 2.15.

\section{General procedure for catalytic reactions of 1-3 with aryl halides in $\mathrm{C}_{6} \mathrm{H}_{6}$}

A solution of 1-3 $(0.01 \mathrm{mmol})$, aryl halides $(2.0 \mathrm{mmol})$ and base $(2.0 \mathrm{mmol})$ in dry benzene $(20 \mathrm{~mL})$ in nitrogen flushed quartz tube was additionally degassed by bubbling nitrogen thru for
5 min. After irradiation for 3-8 $\mathrm{h}$ in the ice-water bath, the solvent was removed under the reduced pressure. The residue was chromatographed in air on silica gel using petroleum ether as eluent. The corresponding biphenyl products were obtained as colorless solids in yields of $26-68 \%$.

\section{Crystallography}

Single crystals of complexes 1, 6, 9, and 11 (CCDC 15207231520726) suitable for X-ray diffraction were obtained by crystallization from $n$-hexane/ $\mathrm{CH}_{2} \mathrm{Cl}_{2}(1: 1)$. Data collection was performed on a Bruker SMART 1000, using graphitemonochromated Mo $K \alpha$ radiation ( $\omega-2 \theta$ scans, $\lambda=0.71073 \AA$ ). Semiempirical absorption corrections were applied for all complexes. The structures were solved by direct methods and refined by full-matrix least squares. All calculations were using the SHELXTL-97 program system. The crystal data and summary of X-ray data collection are presented in Table 3.

\section{Acknowledgements}

This work was financially supported by the National Natural Science Foundation of China (No. 21002069 and 21572160), the Natural Science Foundation of Tianjin (No. 14JCYBJC20300), and the Program for Innovative Research Team in University of Tianjin (TD12-5038).

\section{Notes and references}

1 J. P. Kleiman and M. Dubeck, J. Am. Chem. Soc., 1963, 85, 1544. 
2 P. G. Bomben, K. C. D. Robson, B. D. Koivisto and C. P. Berlinguette, Coord. Chem. Rev., 2012, 256, 1438.

3 H.-F. Chen, C. Wu, M.-C. Kuo, M. E. Thompson and K.-T. Wong, J. Mater. Chem., 2012, 22, 9556.

4 (a) G. C. Volugioukalakis and R. H. Grubbs, Chem. Rev., 2010, 110, 1746; (b) C. Samoilowicz, M. Bieniek and K. Grela, Chem. Rev., 2009, 109, 3708.

5 (a) D. A. Alonso and C. Nájera, Chem. Soc. Rev., 2010, 39, 2891; (b) A. Zapf and M. Beller, Chem. Commun., 2005, 431; (c) I. P. Beletskaya and A. V. Cheprakov, J. Organomet. Chem., 2004, 689, 4055; (d) W. A. Herrmann, V. P. W. Böhm and C.-P. Reisenger, J. Organomet. Chem., 1999, 576, 23; (e) I. Omae, Coord. Chem. Rev., 2004, 248, 995. 6 (a) H. Cao, L.-H. Cai, C.-X. Wang, X.-H. Zhu, Z.-M. Li and X.-F. Hou, J. Organomet. Chem., 2015, 775, 60; (b) A. Grabulosa, A. Mannu, E. Alberico, S. Denurra, S. Gladiali and G. Muller, J. Mol. Catal. A: Chem., 2012, 363-364, 49; (c) R. Cerón-Camacho, V. Gómez-Benítez, R. L. Lagadec, D. Morales-Morales and R. A. Toscano, J. Mol. Catal. A: Chem., 2006, 247, 124; (d) W. Baratta, P. Da Ros, A. Del Zotto, A. Sechi, E. Zangrando and P. Rigo, Angew. Chem., Int. Ed., 2004, 43, 3584; (e) P. Dani, T. Karlen, R. A. Gossage, S. Gladiali and G. van Koten, Angew. Chem., Int. Ed., 2000, 39, 743.

7 (a) P. Spellane, R. J. Watts and A. Vogler, Inorg. Chem., 1993, 32, 5633; (b) F. W. M. Vanhelmont, H. U. Güdel, M. Förtsch and H.-B. Bürgi, Inorg. Chem., 1997, 36, 5512; (c) F. W. M. Vanhelmont, G. F. Strouse, H. U. Güdel, A. C. Stückl and H. W. Schmalle, J. Phys. Chem. A, 1997, 101, 2946; (d) F. W. M. Vanhelmont, M. V. Rajasekharan, H. U. Güdel, S. C. Capelli, J. Hauser and H.-B. Bürgi, J. Chem. Soc., Dalton Trans., 1998, 2893; (e) X.-H. Liu, I. Manners and D. W. Bruce, J. Mater. Chem., 1998, 8, 1555.

8 (a) Y. Kuninobu, Y. Nishina, A. Kawata, M. Shouho and K. Takai, Pure Appl. Chem., 2008, 80, 1149; (b) Y. Kuninobu, H. Ueda, A. Kawata and K. Takai, J. Org. Chem., 2007, 72, 6749; (c) Y. Kuninobu, Y. Tokunaga, A. Kawata and
K. Takai, J. Am. Chem. Soc., 2006, 128, 202; (d) Y. Kuninobu, Y. Inoue and K. Takai, Chem. Lett., 2006, 35, 1376; (e) Y. Kuninobu, A. Kawata and K. Takai, J. Am. Chem. Soc., 2005, 127, 13498.

9 (a) Y. Kuninobu, T. Nakahara, P. Yu and K. Takai, J. Organomet. Chem., 2011, 696, 348; (b) Y. Kuninobu, Y. Nishina, T. Matsuki and K. Takai, J. Am. Chem. Soc., 2008, 130, 14062; (c) Y. Kuninobu, Y. Nishina, M. Shouho and K. Takai, Angew. Chem., Int. Ed., 2006, 45, 2766.

10 (a) Y. Kuninobu, T. Seiki, S. Kanamaro, Y. Nishina and K. Takai, Org. Lett., 2010, 12, 5287; (b) Y. Kuninobu, Y. Nishina and K. Takai, Tetrahedron, 2007, 63, 8463; (c) Y. Kuninobu, Y. Nishina, C. Nakagawa and K. Takai, J. Am. Chem. Soc., 2006, 128, 12376.

11 (a) Y. Kuninobu, Y. Fujii, T. Matsuki, Y. Nishina and K. Takai, Org. Lett., 2009, 11, 2711; (b) Y. Kuninobu, Y. Nishina, K. Okaguchi, M. Shouho and K. Takai, Bull. Chem. Soc. Jpn., 2008, 81, 1393.

12 E. Lindner, G. Funk and S. Hoehne, Chem. Ber., 1981, 114, 2465.

13 N. I. Gapotchenko, N. V. Alekseev, N. E. Kolobova, K. N. Anisimov, I. A. Ronova and A. A. Johansson, J. Organomet. Chem., 1972, 35, 319.

14 K.-L. Lu, H.-H. Lee, C.-M. Wang and Y.-S. Wen, Organometallics, 1994, 13, 593.

15 (a) B. Zhu, X. Huang and X. Hao, Dalton Trans., 2014, 43, 16726; (b) B. Zhu, X. Huang and X. Hao, Eur. J. Inorg. Chem., 2014, 5932.

16 S. Zolezzi, S. A. Moya, G. Valdebenito, G. Abarca, J. Parada and P. Aguirre, Appl. Organomet. Chem., 2014, 28, 364.

17 H. Riihimäki, T. Kangas, P. Suomalainen, H. K. Reinius, S. Jääskeläinen, M. Haukka, A. O. I. Krause, T. A. Pakkanen and J. T. Pursiainen, J. Mol. Catal. A: Chem., 2003, 200, 81.

18 R. B. Bedford and M. E. Limmert, J. Org. Chem., 2003, 68, 8669. 